таких кодексов часто не обеспечивается надежными механизмами, что ограничивает сферу их применения и эффективность.

Европа поставила перед собой достойную цель: стать климатически нейтральным континентом к 2050 году, стремясь к «нулевому загрязнению» [5]. Но в глобальном мире минимизация антропологического воздействия на климатические процессы в одном регионе, даже если речь идет о макрорегионе, недостаточна. Необходимы совместные усилия мирового сообщества. Они могут включать в себя интеграцию и объединение различных массивов данных, сокращение цифрового неравенства, формирование международного экспертного сообщества, представленного всеми государствами мира, способного принимать обоснованные решения.

12 терабайт данных в день, собираемых только «Коперником», а также иные данные о Земле и об изменении климата не должны применяться неразумно. Хранилище климатических данных может быть использовано и в целях устойчивого развития планеты, и для удовлетворения коммерческих и политических потребностей отдельных стейкхолдеров. Принципиальное значение имеет то, какая из этих целей имеет приоритетное положение. Умными должны быть не только города, экономики и транспортные средства, но и нормы по защите окружающей среды.

\title{
ЛИТЕРАТУРА
}

1. Hassani, H., Huang, X. \& Silva, E. Big Data and Climate Change / H. Hassani, X. Huang, E. Silva // Big Data Cogn. Comput. - 2019. - Vol. 3, iss. 1. P. 1-17. doi: 10.3390/bdcc3010012.

2. Copernicus Climate Change Service [Electronic resource].-Mode of access: https://www.copernicus.eu/en/ services/climate-change.- Date of access: 01.03.2020.

3. Equipping farmers in Kenya to overcome climate change [Electronic resource].-Mode of access: https://climate. copernicus.eu/equipping-farmers-kenya-overcome-climate-change--Date of access: 06.03.2020.

4. Lanzing, M. "Strongly Recommended" Revisiting Decisional Privacy to Judge Hypernudging in Self-Tracking Technologies / M. Lanzing // Philos. Technol.-2019.-Vol. 32.-P. 549-568.. https://doi.org/10.1007/s13347-018-0316-4.

5. Communication: A European strategy for data [Electronic resource].-Mode of access: https://ec.europa.eu/info/ publications/communication-european-strategy-data en.-Date of access: 27.02.2020.

\section{BASIC ASPECTS OF MANIFESTATION OF VULNERABILITY IN PENITENTIARY MEDICINE}

\section{ОСНОВНЫЕ АСПЕКТЫ ПРОЯВЛЕНИЯ УЯЗВИМОСТИ В ПЕНИТЕНЦИАРНОЙ МЕДИЦИНЕ}

\author{
V. Cojocaru, V. Ojovanu, I. Banari \\ В. И. Кожокару, В. И. Ожовану, И. П. Банарь
Nicolae Testemitanu State University of Medicine andPharmacy of the Republic of Moldova Chisinau, Republic of Moldova prviorelcojocaru@gmail.com \\ Государственный университет медицины и фрармации им. Николае Тестемицану, \\ ә. Кишинэу, Республика Молдова
}

Penitentiary medicine is the most important subject for discussion of various bioethical problems. Of particular relevance is the issue of vulnerability. Prisoners represent a vulnerable population, but vulnerability increases exponentially in groups with various health problems. One of the features of penitentiary medicine is that it offers medical services to prisoners with various degrees of vulnerability: "double" if the patient is a minor or an elderly prisoner, and "triple" if severe chronic illness, disability or mental disorders are added to this. An analysis of penitentiary medicine from a bioethical point of view should be preceded by the identification of the main components of this specific environment with a special vital status. The first of them is to determine the specifics of the penitentiary environment in the context of vulnerability issues. The second is a characteristic of the forms of vulnerability of prisoners. The third component is the identification of the diverse manifestations of the vulnerability of prisoners in the medical aspect.

Пенитенциарная медицина является важнейшим предметом обсуждения различных биоэтических проблем. Особое значение отводится вопросу уязвимости. Заключенные представляют собой уязвимый контингент, однако степень уязвимости экспоненциально вырастает в группах с различными проблемами здоровья. Одна из особенностей пенитенциальной медицины состоит в том, что обслуживает заключенных с различными степенями уязвимости -,двойной”, если пациентом является малолетний или пожилой заключенный; „тройной”, если к этому прибавляется тяжелая хроническая болезнь, инвалидность или психические расстройства. Анализу пенитенциальной медицины с биоэтических позиций должен предшествовать выявление 
основных компонентов данной специфической среды с особенным жизненно-бытовым статусом. Первым из них является определение специфики пенитенциальной среды в контексте проблем уязвимости. Вторым это характеристика форм уязвимости у заключенных. Третьим компонентом выступает выявление многообразных проявлений уязвимости заключенных в медицинском аспекте.

Keywords: bioethics, vulnerability, medicine, prisoners, patients, penitentiary.

Ключевые слова: биоэтика, уязвимость, медицина, заключенные, пациенты, тюрьма.

https://doi.org/10.46646/SAKH-2020-1-68-71

For a clearer perception of the subject, it is necessary to proceed with the characterization of the specificity of the prison environment in the context of vulnerability. This existential entourage, regardless of area and specific becomes the subject of interdisciplinary research including medical, ethical, legal, sociological, psychological, religious etc aspects. A peculiarity of the research of this micro-environment of social habitat consists that it is composed of the ones limited in space and in the communication actions. An important role in the detention car, which is one of isolation, rests with the actions of behavioral and spiritual recovery of the individual deprived of liberty. Part of this pertains to the medical system. In the medical approach, specific to the prison environment, it is necessary to mention the factors that distinguish a patient deprived of liberty from a patient living in a free society. The detained patient is highlighted by the general vulnerability, facilitated by the condition of freedom itself, and the special one, characterized by groups of vulnerable convicts - women, minors, mentally ill, drug addicts, foreign citizens, HIV-AIDS infections, TB, etc. Eliminating the vulnerability of the convicted person in general, in this system, is impossible, but its reduction/improvement is possible by organizing actions that would weigh the quality of life. The vulnerability of the detainee from the moment of arrest is fully manifested in the distortion of these values: of life and health, first and foremost. Both meanings being autonomous but, at the same time, subordinated by various existential features. The support of a spiritual climate accepted by the convict during this period rests with the spiritual counselors.

The primary factor that triggers the spiritual "deficit" is considered the simple detention of the inmate to ,interact with a potential partner, and this interaction makes him vulnerable to incompetence or opportunism" [1, p.325]. People deprived of liberty are all vulnerable, due to lack of physical freedom, of space, family and society isolation, professional activity and a constrained form of spiritual freedom. The pressing problem of bioethics, the vulnerability of the prisoners, remains, altogether, and in the view of the legal, sociological, psychological, ethical studies, etc. The methodological principle of the vulnerability study in the penitentiary environment must be realized in the perspective of three senses ways. First, the approach to vulnerability in the general sense, whether or not the human individual is deprived of liberty, is distinctive in all living beings, possessing traits equivalent to fragility and death. Simultaneously with the fact that man is powerless in the face of these phenomena, the increase of vulnerability also comes from a state of constrained freedom. From this point of view, the vulnerability is a universal manifestation of the existence of the living, not only of the human existence Another sense of vulnerability focuses directly on the individual deprived of liberty, considered vulnerable in terms of vitality, sovereignty, professional and cultural exercise, isolation, etc. From this point of view, all detainees are vulnerable, so the lack of full freedom in various actions favors the vulnerability in exercising full autonomy. The third sense is characterized not only by the general vulnerability of the detainee but also by certain categories of detainees such as: women, minors, the elderly, convicted with mental and physical impairments, foreign citizens, HIV-AIDS infections, etc.

It is difficult to challenge the detainee's vulnerability reported to the conditions and rules of the private environment, but it can be improved by various methods of spiritual counseling that contribute to the result of two successive decisions: engaging in discussions and interacting in a constructive, trust-focused dialogue. Here, using the methods of general spiritual counseling, emphasizing the mechanisms of effective communication according to the model of the dialogue, there are propitious reasons for trusting the spiritual assistant, first of all, identifying the precautionary means exceeding the expected benefits, either for a certain occasion or for the entire detention period. In the penitentiary environment, a general problem persists, which has not been overcome even in the European countries: the distrust in the unknown individual.

Particularly important is addressing issues of vulnerability to the prisoner contingent. The existence of vulnerable or vulnerable behaviors in the penitentiary environment amplifies the potential of already existing problems. These groups may easily become the target of aggression or be intermediaries forced to do immoral acts. Already being victimized, they tend to be vulnerable to other forms of victimization. These types of manifestations, ,are not limited only to the appearance of physical weakness, they are superimposed on other characteristics to increase the danger of being attacked" [2, p.269]. Through the effect of impunity and vulnerability, the risk of the person deprived of liberty to be attacked increases - the consequence of public demonstrations of weaknesses, which increases the strengthening of the vulnerability. Examination methods of spiritual counseling of this category of convicts focuses on avoiding aggression, achieved through two strategies: In order to reduce the vulnerability, the detainee is proposed to withdraw from the status of the interlaced world, using tactics to increase his religiosity, and the second strategy consists in identifying in the individual deprived of liberty, named in the language of the interlaced world "obijduit", a reputation of a person with difficult behavior, focused on moral values: dignity and fairness. Cultivating these values in the environment of vulnerable prisoners is achieved with a common and systematic contribution, involving them in the process of special spiritual counseling: organizing meetings with 
the spiritual assistant, lessons, active participation in the activities of the counselor, etc. Overcoming these manifestations proceeds from identifying the deprived individuals of deviant behavior and discussing the specificity of this behavior in the penitentiary environment.

Exceeding the shades of prisoner vulnerability and various vulnerable groups in the prison system, another important bioethics topic emerges: quality of life, deriving in others, such as: perpetuating life and diminishing suffering, freedomof-life ratio, non-traditional sexuality and sexual deviations, suicide, self-aggression and self-mutilation, etc. These bioethics topics researched in the penitentiary environment are becoming almost taboo phenomena in the scientific sphere. However, the objectives of the current policies - procedural-national and international criminal penalties are outlined to maintain a vital quality of survival in the penitentiary environment. American bioethicists have drawn greater attention to formulating the concept of ,quality of life”, so in the process of health care, the notion focuses on five basic criteria, which maintain, restore or provide functional equivalents to normal human vitality, adaptable to the prison environment. The five criteria are: adequate nutrition and shelter; safe sanitary conditions at home and at work; rest and other characteristics of a healthy lifestyle; medical services for prevention, healing and rehabilitation; non-medical personal assistance services: social and spiritual. In this context, the mentioned criteria are extremely modest in the penitentiary institutions of the Republic of Moldova.

Following the researches, it was found that the most important opportunity is found in a difficulty both on a global level and the local one regarding the spiritual-moral status of the prisoner. Even if the special investigations focused on the life of the penitentiary environment are being shaped not only at the global level, but also at the domestic level, they are marked by an overwhelming moral crisis, expressed through the obvious pathos of the existing value system. So far, there is no standard of spiritual-moral appreciation of the detainee, characterized by vulnerability and suffering, so HT Enghelhardt is right justifying „How should we compare the values of freedom, equality, prosperity and security in articulating social assistance policy? The comparison will depend on the standard chosen for comparison. Moreover, the search for a good might be in tension with the search for a different good" [3, p.138]. Lack of standards of appreciation of the convict's spiritual-moral status will further contribute to the identification of multiple beneficial solutions in elucidating the deficiency, adapted to the domestic penitentiary environment. The spiritual counseling provided qualitatively, defines and elaborates mechanisms for raising the spiritual-moral level of the prisoner, but not for appreciating this status. The comparison of the values in the penitentiary environment depends on the condition of the habitat, the culture or the subculture of the prisoner and the multitude of interdisciplinary premises of appreciation, all related to the legal status of the individual deprived of liberty.

Therefore, a multitude of situations and relationships take place in the penitentiary environment and this condition the prisoners' vulnerability in the medical field. One category of factors that negatively influences the condition of the individual deprived of liberty is also considered the existence in the penitentiary habitat of „extra” conditions of isolation: the presence of manipulators, defenders, mentally ill, simulators of illness, violence, rapists, perverts and manifestation of perversions, etc., giving the environment a special form of isolation, considered complex. These manifestations occur in the penitentiary environment because there are people seeking to gain benefits, or to exploit the lack of attention, the consequence being the interpersonal distrust and the suspicion that these individuals trigger. Fear appears as a common outcome in the lifestyle of many convicts, so many of them seek to avoid certain risk areas in the penitentiary, an almost equal number spending more time in cells as a precautionary method against victimization, than in the reduced freedom of the penitentiary Many people deprived of their liberty keep close to objects that can be used as self-defense weapons, identify individuals who could be used as protection barriers against the aggressors, taking advantage of the acute vulnerability of others. Some of the convicts find that the display in the static discipline of the penitentiary, related to the frequent presence of violence, the probability and the possibility of victimization through physical, sexual aggression, etc., negatively influences the habitat condition in this social micro-environment, thus forcing the individual deprived of liberty to negotiate the dominant intentions of others, focused on the lack of respect for what represents the well-being and quality of life in the environment. The convicts who do not feel safe during the detention, interact very difficult in the social and medical counseling programs, thus becoming irascible, rejecting most of the institutional correction platforms.

A special category of detainees with special vulnerability is the persons with sexual crimes, these being the social-dangerous acts provided by the criminal law, committed intentionally, which abusively violates the moral rule established in society regarding sexual relations. Criminal law experts say that ,the criminal law does not act as a positive regulator of sexual relations, but establishes the prohibition to commit acts that go in blatant contradiction with the principles of sexual ethics and of the natural rules of coexistence, ceased in our society" [4, p.174]. With the contribution of this postulate, the Criminal Code of the Republic of Moldova has pointed out a category of offenses that focus on the sexual freedom and inviolability of the person, defining them in the following position: rape. Violent actions of a sexual nature (Articles 171 and 172); Sexual harassment (art. 173) and sexual relations with a person who has not reached the age of 16 (art. 174 and 175).

The category of vulnerable prisoners includes also those who are addicted to drugs, alcohol, gambling, etc. In the penitentiary environment, even from the moment of deprivation of liberty, these categories of prisoners are included in various detoxification procedures, and bringing them back to the real world causes various problems, both somatic and spiritual. 
For the Republic of Moldova and the post-socialist countries, it becomes difficult to overcome the periods of crisis among young drug users, caused on one hand by the soviet culture, and on the other by ,atheist ideologies, secularism, totalitarianism, as products of European culture, which are putting the contemporary man in the situation of facing the disorientation and the lack of a spiritual and cultural goal" [5, p.243].

In many countries, convictions for violating drug prohibition rules have increased considerably. Therefore, in EU countries up to $30 \%$ of the convicts have a history of injection drug use, and most of them meet the criteria for diagnosing physical or mental drug addiction. The side effects are multiple, both somatic and spiritual, caused by the addiction of using, and the toxic-addiction climaxes with the adaptation to a deviant and delinquent behavior until suicide. Some of the researchers of the phenomenon of drug addiction claim that the main cause of the drug addiction is the condition „considered at the present moment to be the man's desire to expand his intellectual and physical possibilities” [6, p.33]. In these crisis situations caused by the rules of the habitat deprived of freedom and drug addiction, the convicted person will be susceptible to self-harm or even suicide, and the sudden interruption of drug use will disturb his emotional, spiritual and somatic health.

The cataloging of this category of convicts in vulnerable groups is manifested by the lower ranking on the hierarchical scale of the prisoners, facing the prejudices of their colleagues and the staff of the penitentiary institution. According to etiology, there are various forms of treatment, focused on motivational techniques, but one of the most successful, in parallel with the medication, is the spiritual counseling, adapted to the penitentiary environment, focused on the moral-biomedical improvement of the human behavioral disorders. From this point of view, the spiritual assistant is committed to counseling this category of convicts, avoiding promises and compromises, even if he is subjected to blackmail. In this context, the assistant abandons the counseling procedure and restarts it after the drug detoxification.

A significant factor that needs to be quantified is the high number of prisoners with mental disorders, which are producing a spiritual discomfort to the healthy convicts. Psychiatric-symptomatic convicts become especially vulnerable, compared to the healthy ones, often causing conflicts between prisoners. For the majority, the vulnerability is intensified and the recovery process complicates because some have ,problems related to arithmetic and literacy [...] some of them have a level of intelligence below average" [7, p.29].

In the penitentiary environment, trust is a value not only in the medical aspect, focused on the patient's confidence, the professional authority of the doctor, the medical mystery, the medical errors, etc., and it is a prime objective in the classification of inter-human and inter-social relationships. If the value of trust in the medical aspect of the free society is focused on the possibility of the patient to choose the doctor, then the system deprived of freedom prohibits this opportunity, becoming an additional factor to strengthen the prisoner's vulnerability, a topic discussed in the European prison ethics. Using informed consent, these situations can be solved in medical terms, facilitating the fact of strengthening the doctor-patient relationship. The lack of a stable relationship between the prisoners and other employees of the penitentiary institution causes various methods of identifying trusted persons, both among the prison staff and the cell colleagues.

In order to identify this category of convicts, the employees of the institution are subjected to tests, which determine the human dignity and purpose of the services. An exercise often explored is the examination of confidentiality, which all the employees of the institution pass, resulting in the hierarchy of employees in the view of the convicts. According to the same criterion, the spiritual counselor is also assessed and his dignity, sometimes being most often probed to justify the moral respect he promotes. This becomes especially important because the role of counselor can be entrusted to any doctor.

Therefore, penitentiary medicine is characterized by a stable state of vulnerability of its specific contingent of patients - patients held with a diverse spectrum of diseases according to the typology and severity of their manifestation. A number of pathologies have been found in this specific environment of existence and others were already present in the convicts. In the penitentiary not only the medical treatment are facing difficulties, but also the doctor, the medical nurse. In the most post-Soviet and post-socialist states, their status is uncertain, and they are often forced by the prison administration to make certain decisions. Because the diseases of the detention environment are specific, their treatment becomes specific again through the difficulty of treating freely and efficiently, this fact fully nourishes the vulnerability of the prisoners. Special large-scale, interdisciplinary studies under the aegis of bioethics would greatly facilitate the resolution of the health and quality of life of the prisoners.

\section{ЛИТЕРАТУРА}

1. Elster, J. Comportamentul social: fundamentele explicației în științele sociale / J. Elster. - București: Ed. ALL, 2013. $-447 \mathrm{p}$.

2. O'Dannell, I. Routine Victimization in Prison / I. O'Dannell // The Howard Journal of Crime and Justice. - 2002. Nr. 37(3). - P. 266-279.

3. Enghelhardt, T. The Ortodox Christian View of suffering / T. Enghelhardt // Sufferingand Bioettics. Coord. R. Green, W. Palsant. - New York: Oxford University Press, 2014. - P. 249-261.

4. Brînză, S. Infracțiuni contra vieții, sănătății, libertății și demnității persoanei / S. Brînză. - Chișinău, 1999. - 234 p.

5. Popescu, L. Pastorația copiilor și a tinerilor în noul context social / L. Popescu // Teologie și Educație la Dunărea de Jos. - Galați: Ed. Episcopiei Dunării de Jos, 2003. - P. 243-259.

6. Danion, V. Lanțurile drogurilor / V. Danion. - Galați: Ed. Egumenița, 2004. - 265 p.

7. Lehtmets, A. Îngrijirea sănătății și etica medicală în penitenciare / A. Lehtmets, J. Pont. - Chișinău: Consiliul Europei, 2016. -88 p. 


\title{
СОВРЕМЕННЫЕ ПРОБЛЕМЫ БИОМЕДИЦИНСКОЙ ЭТИКИ MODERN PROBLEMS OF BIOMEDICAL ETHICS
}

\author{
O. В. Летов \\ O. Letov \\ Институт научной информации по общественным наукам РАН, \\ г. Москва, Российская Федерация, \\ mramor59@mail.ru \\ Institute of Scientific Information on Social Sciences of the RAS, \\ Moscow, Russian Federation
}

\begin{abstract}
Статья посвящена современным проблемам биомедицинской этики. Целью исследования стволовых клеток является использование или манипулирование стволовыми клетками для восстановления утраченной ткани. Подобные методы лечения порождают такие проблемы, как уязвимость тяжело больных, применимость норм и правил медицинской этики, наличие или отсутствие информированного согласия пациента. Необходимость доступа граждан к правительственной и публичной информации для проверки их честности должна сочетаться с защитой личной жизни граждан от нежелательного воздействия. Теория мотивации ожидания Виктора Врума - когнитивная философия, помогающая объяснить индивидуальные различия в трудовой мотивации индивида; в ее рамках описываются поведенческие модели людей, помогающие выбрать конкретное действие среди различных альтернатив.
\end{abstract}

The article is devoted to the modern problems of biomedical ethics. The goal of stem cell research is to use or manipulate stem cells to restore lost tissue. Such treatment methods cause problems such as the vulnerability of seriously ill patients, the applicability of norms and rules of medical ethics, the presence or absence of informed consent of the patient. The need for citizens to have access to government and public information in order to verify their integrity must be combined with protecting citizens' personal lives from undesirable effects. Victor Vroom's theory of expectation motivation is a cognitive philosophy that helps explain individual differences in an individual's work motivation. This theory describes the behavioral patterns of people in order to select a specific action among various alternatives.

Ключевые слова: стволовые клетки; аутологичные клетки; информированное согласие пациента; этические принципы; конфликт; принцип свободы; принцип конфиденциальности; право на информацию; моральный выбор; этические принципы; мотивация донора; альтруизм; прагматизм.

Key words: stem cells; autologous cells; patient informed consent; ethical principles; conflict; principle of freedom; confidentiality principle; right to information; moral choice; ethical principles; donor motivation; altruism; pragmatism.

https://doi.org/10.46646/SAKH-2020-1-72-75

Растущая индустрия непроверенных методов лечения стволовыми клетками сосредоточена на использовании аутологичных клеток, чтобы позволить пациентам получать выгоду от медицинского лечения их собственными, а не донорскими клетками. В настоящее время методы лечения с использованием аутологичных клеток носят экспериментальный характер. Многие ученые и врачи считают подобные методы лечения неэтичными. В некоторых странах были предприняты попытки строго отрегулировать непроверенную терапию стволовыми клетками (далее-СК). Стволовые клетки - это клетки, которые могут трансформироваться в другие типы клеток, а также способны самообновляться и в конечном итоге вызывать увеличение числа клеток. Целью исследования СК является их использование или манипулирование ими для восстановления утраченной ткани. Подобные методы лечения порождают такие проблемы, как уязвимость тяжело больных, применимость норм и правил медицинской этики, наличие или отсутствие информированного согласия пациента.

Вместе с тем, некоторые пациенты, их опекуны и группы поддержки пациентов выступают за сокращение масштабов государственного регулирования так, чтобы эти методы лечения стали более доступными, особенно процедуры, в которых используются аутологичные клетки, полученные у самого пациента. Эти группы полагают, что пациенты имеют неотъемлемое право на неограниченное использование собственных стволовых клеток. Они утверждают, что правительственные регулирующие органы не должны вмешиваться в этот процесс. Вопрос о праве собственности на аутологичные клетки имеет глубокие последствия для будущего регулирования методов лечения с помощью стволовых клеток. В настоящее время не существует юридического прецедента на владение регенеративными тканями человека. Сложно найти серьезные этические и юридические основания подобного владения. Эта тема, вероятно, станет источником будущих этических и правовых дискуссий.

При проведении аутологичной клеточной терапии врач применяет законные умения и навыки, и действует как агент от имени пациента, на основании того, что пациент имеет право собственности на свои аутологичные клетки. 